\title{
Using Waterfall Method to Design Information System of SPMI STIMIK Sepuluh Nopember Jayapura
}

\author{
$1^{\text {st }}$ Elvis Pawan, $2^{\text {nd }}$ Rosiyati H.H Thamrin, $3^{\text {rd }}$ Patmawati Hasan. $4^{\text {th }}$ Sariyati H.Y. Bei, $5^{\text {th }}$ Paulisen Matu \\ 1,2,3,4,5 Program Studi Teknik Informatika \\ STIMIK Sepuluh Nopember Jayapura \\ 1,2,3,4,5Jl. Ardipura II No.22B Polimak Jayapura Selatan Jayapura - Papua \\ 1elvispawan09@gmail.com, ${ }^{2}$ rosiyati1011@gmail.com, ${ }^{3}$ patmawatihasan@gmail.com, \\ ${ }^{4}$ sariyatibei@gmail.com, 5 matupaulizen@gmail.com
}

\begin{abstract}
Conventional filing of SPMI documents is a problem experienced by STIMIK Sepuluh Nopember Jayapura, archiving in this way can result in documents being lost or scattered, in addition to causing difficulties in finding documents during internal and external audits. This study aims to assist institutions in improving their filing systems, so that SPMI data or documents can be stored properly and easily obtained when needed. In designing the information system SPMI STIMIK Sepuluh Nopember Jayapura, using the waterfall method and data modeling using data flow diagrams, while in system testing using the blackbox method and user acceptance test. This research produces an SPMI information system that can be used to archive all types of documents owned by the internal quality assurance agency Based on table 2, as many as $86 \%$ of the answers of respondents who answered were very correct (SB), as many as $12 \%$ of respondents who answered correctly $(B)$ and $2 \%$ answered doubtful or neutral.
\end{abstract}

Keywords : SPMI, DFD, Waterfall, Information Systems.

\section{INTRODUCTION}

It is undeniable that information technology greatly affects human life, its use can be felt in various fields, ranging from transportation, health, including education such as universities [1]. However, in contrast to the Internal Quality Assurance Agency STIMIK Sepuluh Nopember, Jayapura in carrying out its operations has several problems including the archiving of SPMI documents which are still done conventionally so it is very difficult if someone or a team needs these documents, archiving is done by storing documents in a cabinet that is given a code, problems will arise when someone takes the file and does not return it to its original position. With this research, it tries to provide a new solution to the STIMIK Sepuluh Nopember Jayapura college in particular, a quality assurance institution, with a computerized based system. With the existence of an information system, it is expected that archiving will gradually improve in line with the vision and mission of the quality assurance agency[3].

Several studies that design quality assurance information systems include the implementation of management information systems in improving the quality of education, in this study describes several forms of information systems that can be used in improving the quality of education [2]. Another study is the quality assurance system at the Respati midwifery high school, the study concluded that it is very important to implement an information system in the quality assurance unit besides that this study states that the implementation of making applications must be realized by education administrators [3]. Several other studies that use the waterfall method to design information systems include e-learning information system design, this research only conducts one type of testing using the blackbox method [4], while in this study using two testing methods, namely the blackbox method and the user acceptance test method. (UAT). The next research is the application of the waterfall method in making tracer study applications based on android [5], the difference in this research is that it is website-based and the modeling system uses data flow diagrams, whereas in previous studies using use case diagrams.

\subsection{Research Flow}

\section{RESEARCH METHODS}

There are several important stages carried out in this study, the important steps refer to the waterfall model [6], [4] The steps in this study can be seen in Figure 1.

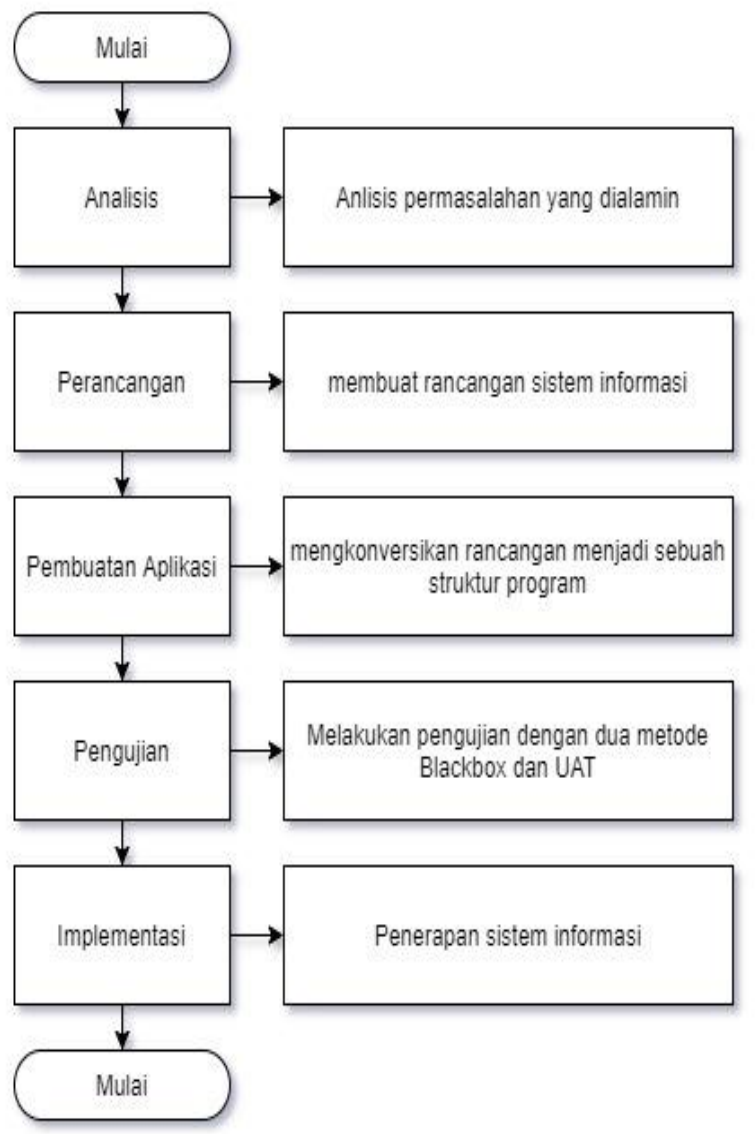

Figure 1. Research Flow 
Peer Reviewed - International Journal

Vol : Vol. 02, Issue 02, May 2021

e-ISSN : 2745-9659

https://ijcis.net/index.php/ijcis/index

Based on Figure 1.The first step starts from analysis, the analysis stage is an initial step to describe the problems that are being experienced by the internal quality assurance agency, the second step is design, at this stage is to create a concept such as data flow diagrams and design of an information system database. suitable to be implemented in the internal quality assurance institute of STIMIK Sepuluh Nopember Jayapura, the third step is making an application, at this stage it aims to translate the results of analysis and design that have been made into a program structure using the PHP programming language. The fourth step is to test the information system that has been created, at this stage two types of testing are carried out, namely using the blackbox method and the user acceptance test (UAT) method, the blackbox method aims to find out whether the functionality of the information system can work properly, then testing using the UAT method aims to find out whether the system created can actually solve the existing problems. The fifth step is the implementation of an information system to resolve the problems that are being experienced by the internal quality assurance agency STIMIK Sepuluh Nopember Jayapura.

\subsection{Data source}

There are two types of data used in this study, namely primary data and secondary data, the primary data source is obtained from interviews with related parties, which are then discussed in a fucus group discussion (FGD) to obtain the real problem, secondary data comes from previous research results such as journals and books.

\subsection{Data Collection Techniques}

To collect data in this study, it was carried out through observation and interviews. In conducting observations, direct observation was made of the current condition of the internal quality assurance institute of STIMIK Sepuluh Nopember Jayapura.

\section{RESULT AND ANALYSIS \\ 3.1 Required System Specifications}

The internal quality assurance information system of STIMIK Sepuluh Nopember Jayapura consists of two categories of users, namely admin and users, admins can access all the features contained in the information system, and can perform create, read, update and delete (CRUD) functions. While users can download and search for documents or data that have been loaded on the information system, the purpose of limiting access rights is that the data contained in the information system can be held accountable.

\subsection{Data Flow Diagram (DFD)}

Data flow diagram is a description of data flow that occurs in a system that is being developed [7] [8]. Description of flow or data flow diagram of data on information systems can be seen in Figure 2.

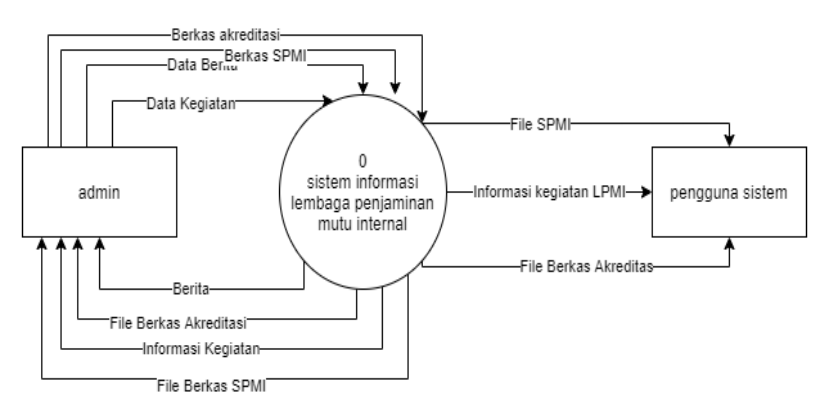

Figure 2. Data Flow Diagram

Based on Figure 2, there are two entities that are directly related to information systems, namely admin and users, the admin is tasked with uploading or inputting data to the information system, and users can download files if needed.

\subsection{Database Design}

The database design is made in the form of an entity relationship diagram (ERD) which can be seen in Figure 3

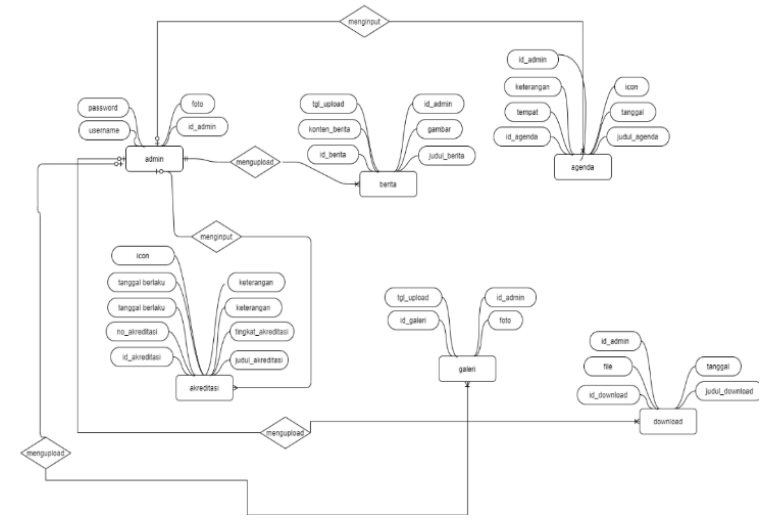

Figure 3. Entity Relationship Diagram (ERD)

\subsection{User Interface}

The user interface is a visual display of the information system of the STIMIK Sepuluh Nopember Jayapura internal quality assurance agency.

\section{a. Menu Login}

The Login menu can be seen as shown in Figure 4. The menu is useful as a system security, so that not all users can access the information system.

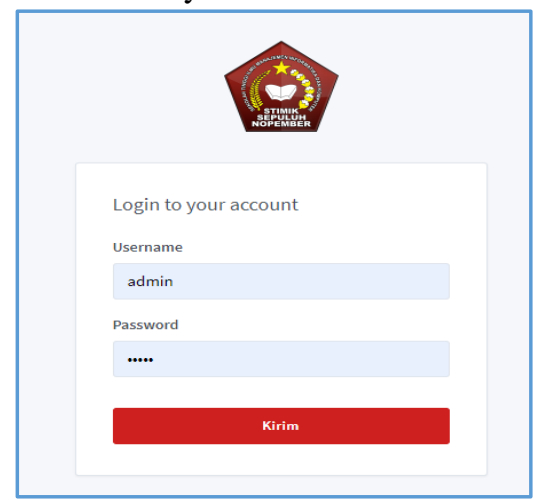

Figure 4. Menu Login 
Peer Reviewed - International Journal

Vol : Vol. 02, Issue 02, May 2021

e-ISSN : 2745-9659

https://ijcis.net/index.php/ijcis/index

In Figure 4 is the login menu user interface, to access the system to the main menu, an admin can enter the user name and password that has been stored in the information system database.

\section{b. Main Course}

The main menu is a page view after a user enters through the login menu, the main menu of the information system can be seen in Figure 5.

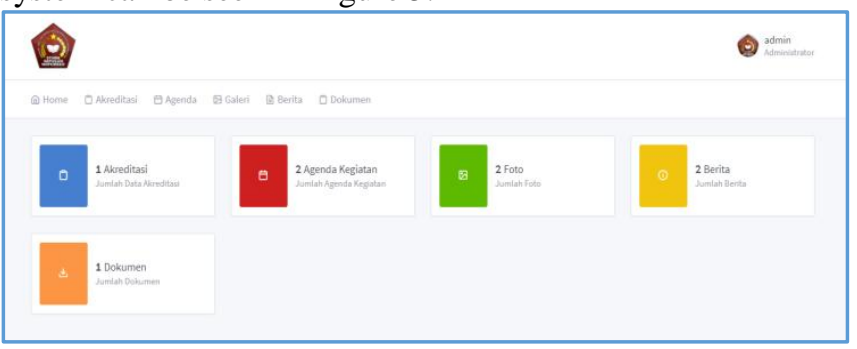

Figure 5. Main course

The main menu in Figure 5 displays the sub-menus that can be accessed by an admin to upload data. The sub menus that appear include the home menu, accreditation, agenda, galleries, news and documents.

\section{c. Accreditation menu}

The accreditation menu can be seen in Figure 6, the menu will appear after an admin clicks the accreditation sub menu on the main menu.

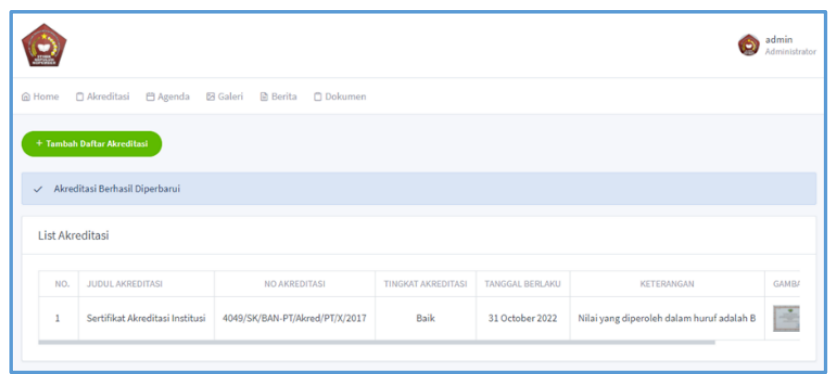

Figure 6. Accreditation Menu

Figure 6 shows the accreditation page on that page an admin can perform CRUD functions on accreditation data

\section{d. Schedule Menu}

The agenda menu can be seen in Figure 7, the menu will appear after an admin clicks the agenda sub menu on the main menu.

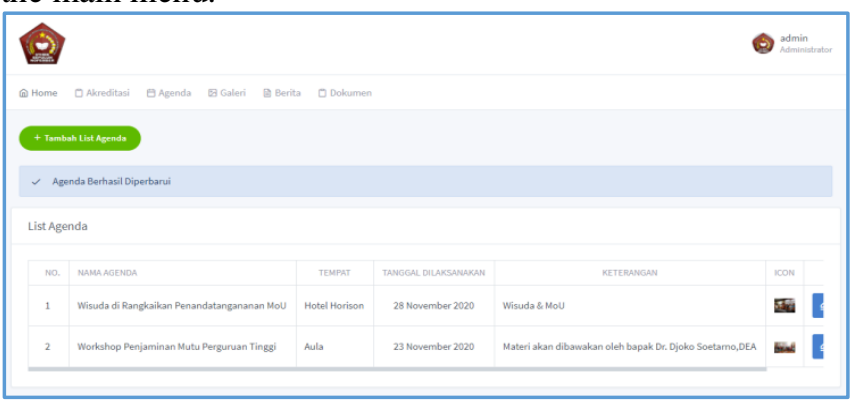

Figure 7. Menu Agenda
Figure 7 shows the agenda page on that page an admin can perform CRUD functions on agenda data at the internal quality assurance agency STIMIK Sepuluh Nopember Jayapura.

\section{e. Gallery Menu}

The agenda menu can be seen in Figure 8, the menu will appear after an admin clicks on the gallery sub menu on the main menu.

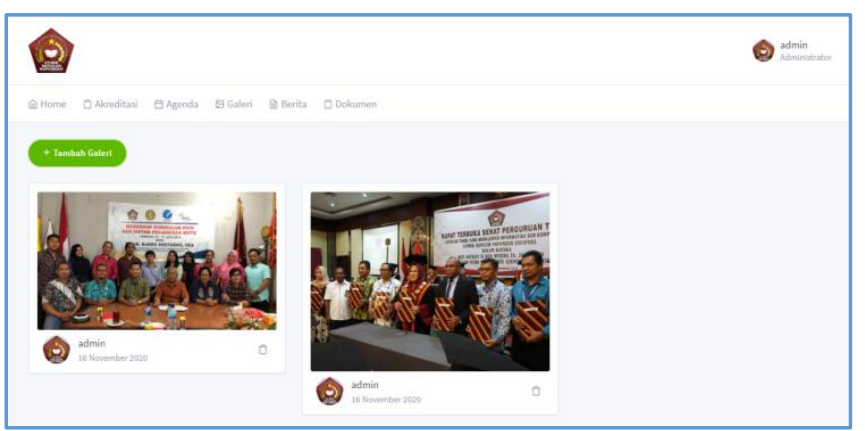

Figure 8. Gallery menu

Figure 8 shows the gallery menu page on that page an admin can perform a CRUD function on the gallery data of the internal quality assurance agency STIMIK Sepuluh Nopember Jayapura, the gallery will contain photos and videos of LPMI activities.

\section{f. News Menu}

The news menu can be seen in Figure 9, the menu will appear after an admin clicks the news sub menu on the main menu.

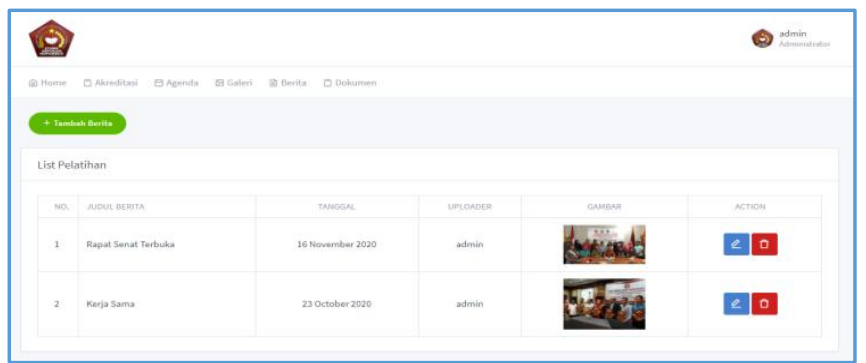

Figure 9. News Menu

Figure 9 shows the news menu page, on that page an admin can perform a CRUD function on the news data of the internal quality assurance agency STIMIK Sepuluh Nopember Jayapura, the news menu contains important events carried out by LPMI.

\section{g. SPMI Document Menu}

SPMI document menu can be seen in Figure 10, the menu will appear after an admin clicks the document sub menu on the main menu 
Peer Reviewed - International Journal

Vol : Vol. 02, Issue 02, May 2021

e-ISSN : 2745-9659

https://ijcis.net/index.php/ijcis/index

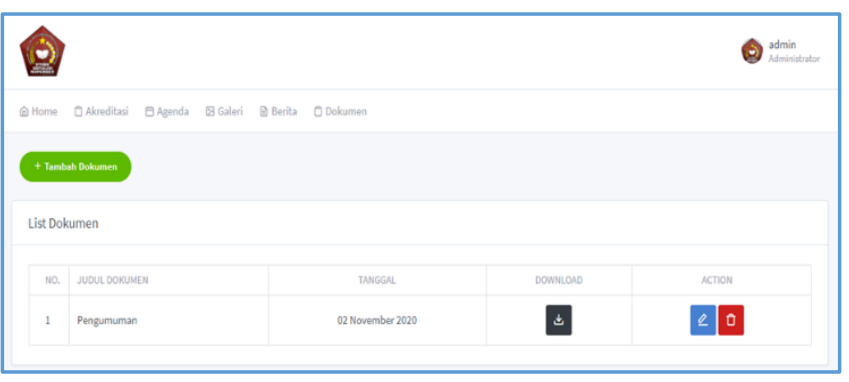

Figure 10. The Document Menu

Figure 10 shows the document menu page, on that page an admin can perform a CRUD function on the document data of the internal quality assurance agency STIMIK Sepuluh Nopember Jayapura, the document menu contains all documents that have been scanned in the form of a pdf file. Some of the documents stored on the menu include policy documents, quality manuals, standard documents, standard operating procedures, SPMI audit results and letters.

\section{h. Home Menu User}

The SPMI information system home menu can be seen in Figure 11, the menu will appear after a user accesses the application.

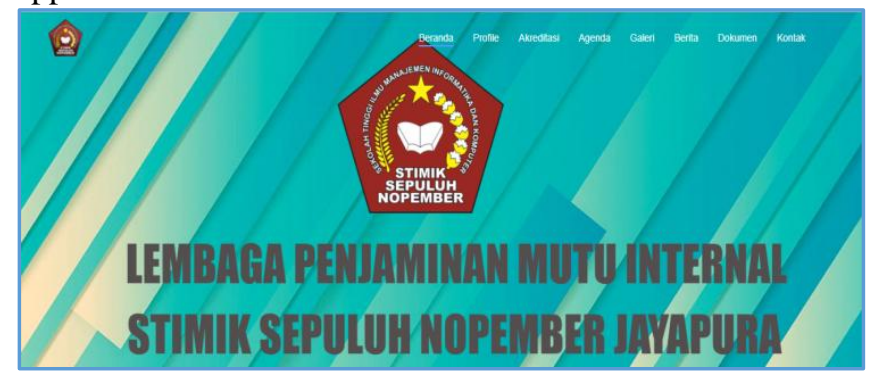

Figure 11. Home Menu

In Figure 11 is a display when the user accesses the information system to search for data or information, the user can download the documents needed, and see the entire series of activities or the agenda of the STIMIK SepuluhNopember Jayapura internal quality assurance agency.

\subsection{System Testing}

This research uses two testing methods, namely testing using the blackbox method and the user acceptance test method.

\section{a. Metode Blackbox}

Testing using the black box method aims to determine the functionality of the information system to work well as for the information system testing scenario of the STIMIK Sepuluh Nopember Jayapura internal quality assurance agency can be seen in table 1 .
Tabel 1. Blackbox Method Testing Scenarios

\begin{tabular}{|c|c|c|c|}
\hline \multirow{2}{*}{ No } & \multirow{2}{*}{ Scenario } & \multicolumn{2}{|c|}{ Test Result } \\
\hline & & Valid & Invalid \\
\hline 1 & $\begin{array}{l}\text { On the login page, enter the } \\
\text { correct user name and } \\
\text { password, it is hoped that } \\
\text { the system will provide } \\
\text { information on successful } \\
\text { login and to the dashboard } \\
\text { page or main menu. }\end{array}$ & $\sqrt{ }$ & \\
\hline 2 & $\begin{array}{l}\text { Page add news data, } \\
\text { hopefully this page can add } \\
\text { data according to user } \\
\text { wishes }\end{array}$ & $\sqrt{ }$ & \\
\hline 3 & $\begin{array}{l}\text { Additional pages gallery, } \\
\text { hopefully this page can } \\
\text { function to add photos in } \\
\text { the system }\end{array}$ & $\sqrt{ }$ & \\
\hline 4 & $\begin{array}{l}\text { Add agenda page, } \\
\text { hopefully this page can add } \\
\text { an agenda of activities }\end{array}$ & $\sqrt{ }$ & \\
\hline 5 & $\begin{array}{l}\text { Document download page, } \\
\text { hopefully this page can be } \\
\text { used to download } \\
\text { documents }\end{array}$ & $\sqrt{ }$ & \\
\hline 6 & $\begin{array}{l}\text { Add page and download } \\
\text { accreditation certificate, } \\
\text { hopefully this page can be } \\
\text { used to download } \\
\text { accreditation certificate } \\
\text { files }\end{array}$ & $\sqrt{ }$ & \\
\hline 7 & $\begin{array}{l}\text { Pages add documents, it is } \\
\text { hoped that this page can } \\
\text { add an activity agenda }\end{array}$ & $\sqrt{ }$ & \\
\hline 8 & $\begin{array}{l}\text { The home page of the user } \\
\text { is hoped to be used to } \\
\text { search and download data } \\
\text { and information }\end{array}$ & $\sqrt{ }$ & \\
\hline
\end{tabular}

Based on table 1, tests have been carried out on all the information system menus totaling 8 and based on testing the functionality of the system using the black box method as many as 8 menus as desired.

\section{b. Metode User Acceptance Test}

The test aims to find out whether the information system of the STIMIK Sepuluh Nopember Jayapura internal quality assurance institution can be used as needed by LPMI and users of the user acceptance test information system can be seen in table 2. 
Peer Reviewed - International Journal

Vol : Vol. 02, Issue 02, May 2021

e-ISSN : 2745-9659

https://ijcis.net/index.php/ijcis/index

Table 2. UAT Testing Scenarios

\begin{tabular}{|c|c|c|c|c|c|c|}
\hline \multirow[t]{2}{*}{ No } & \multirow[t]{2}{*}{ Question } & \multicolumn{5}{|c|}{$\begin{array}{c}\text { Percentage of Respondents' } \\
\text { Answers }(\%)\end{array}$} \\
\hline & & SB & B & $\mathrm{N}$ & KB & $\mathrm{TB}$ \\
\hline 1 & $\begin{array}{l}\text { Does the } \\
\text { Information } \\
\text { System Have a } \\
\text { create, read, } \\
\text { update, delete } \\
\text { (CRUD) } \\
\text { function? }\end{array}$ & 90 & 10 & & & \\
\hline 2 & $\begin{array}{l}\text { Can users } \\
\text { download } \\
\text { documents? }\end{array}$ & 90 & 10 & & & \\
\hline 3 & $\begin{array}{l}\text { Can the } \\
\text { information } \\
\text { system solve } \\
\text { LPMI } \\
\text { problems? }\end{array}$ & 80 & 20 & & & \\
\hline 4 & $\begin{array}{l}\text { Can the } \\
\text { information } \\
\text { system be used } \\
\text { flexibly to } \\
\text { upload or } \\
\text { update data? }\end{array}$ & 90 & 10 & 10 & & \\
\hline 5 & $\begin{array}{l}\text { Are the } \\
\text { information } \\
\text { systems easy to } \\
\text { use? }\end{array}$ & 90 & 20 & & & \\
\hline $\operatorname{Resp}$ & ndents' Answers & $86 \%$ & $12 \%$ & $2 \%$ & $0 \%$ & $0 \%$ \\
\hline
\end{tabular}

Based on table 2, as many as $86 \%$ of the answers of respondents who answered were very correct (SB), as many as $12 \%$ of respondents who answered correctly (B) and $2 \%$ answered doubtful or neutral.

\section{IV.CONCLUSIONS}

There are several conclusions that can be drawn from research on the topic of using the waterfall method in designing an information system for the internal quality assurance institution at STIMIK Sepuluh Nopember Jayapura, including the following : In designing an information system using the waterfall method, errors tend to be reduced because all processes are carried out sequentially, starting from the process of analysis, design, system creation, testing to implementation. However, using the waterfall method also has its drawbacks, now that the time needed for system development is longer. Based on the black box test of the eight menus, the success rate of system functionality was tested with the system developer 's desire of $100 \%$. Testing using the UAT method received a very good response from respondents $86 \%$ who answered very correctly, and $12 \%$ answered correctly, thus this information system is very feasible to be applied to the internal quality assurance agency STIMIK Sepuluh Nopember Jayapura.

\section{REFERENCES}

[1] Andharsaputri, R. L. (2021). Design of Information Systems for the Procurement of Goods and Services on a Desktop, 15 (1), 1-12.

[2] Candra Budi Susila, M. H. (2021). Design and Build a Sales Information System Using the Waterfall Method. Qua Teknika Journal, 11 (1), 18-26.

[3] Hambali, I. (2021). Implementation of Management Information Systems (MIS) in Improving the Quality of the Learning Process, 5 (1), 124-134.

[4] Hendrawana, A., \& Yulianeub, A. (2017). Internal Quality Assurance System (SPMI) (At Respati Sumedang Midwifery Academic). Journal of Informatics Management, 4 (2), 1-10.

[5] L Tobing, D. M., Pawan, E., Neno, F. E., \& Kusrini, K. (2019). Expert System Detects Disease in Rice Plants Using Forward Chaining Method. Sisfotenika, 9 (2), 126. https://doi.org/10.30700/jst.v9i2.440

[6] Pawan, E., Jasuma, A., Arif, A. Y., \& Kusrini, K. (2020). Decision Support Systems Determining the Best Rice Seeds Using the Competence Gap Method Decision Support Systems Determine the Best Rice Seeds Using the Competence Gap Method. Scientific Journal of Information Systems and Informatics Engineering (SISFOTENIKA) STMIK Pontianak, $10 \quad$ (1), 24-36. https://doi.org/http://dx.doi.org/10.30700/jst.v10i1.511

[7] Sadi, Lucitasari, D. R., \& Khannan, M. S. A. (2019). Designing Mobile Alumni Tracer Study System Using Waterfall Method: an Android Based. International Journal of Computer Networks and Communications Security, 7 (9), 196-202. Retrieved from https://search.proquest.com/openview/bb5962be1873287d1c $634 \mathrm{c} 9252177903 / 1$ ?pq-origsite $=$ gscholar $\& \mathrm{cbl}=2044553$

[8] Sukmana, A. P. Y. H. S. H. (2021). Web-Based Library Information System Design Using Waterfall Model. Journal of Informatics Innovation, 6 (1), 49-53. https://doi.org/https://doi.org/10.51170/jii.v6i1.14.

[9] Rais, N. A. R., \& Saputra, R. (2020). Online Sales System Analysis of PT. Nutrifood Indonesia through the distributor CV. Trio Sukses Mandiri Solo With Nutrimart Home Delivery (NHD) Application. International Journal of Computer and Information System (IJCIS), 1(2), 40-46.

[10] Nur, U. C., \& Muqorobin, M. (2020). Development Of Smart Working Assistance Application For J\&T Express Couriers In Juwiring Klaten Branch. International Journal of Computer and Information System (IJCIS), 1(3), 52-54.

[11] Efendi, T. F., \& Krisanty, M. (2020). Warehouse Data System Analysis PT. Kanaan Global Indonesia. International Journal of Computer and Information System (IJCIS), 1(3), 70-73.

[12] Pujianto, H., \& Rokhmah, S. (2021). Analysis of" E-Patient UNS" Application System for Online Registration of UNS Hospital Patients. International Journal of Computer and Information System (IJCIS), 2(1), 9-12.

[13] Muqorobin, M., \& Rais, N. A. R. (2020). Analysis of the Role of Information Systems Technology in Lecture Learning during the Corona Virus Pandemic. International Journal of Computer and Information System (IJCIS), 1(2), 47-51. 
International Journal of Computer and Information System (IJCIS)

Peer Reviewed - International Journal

Vol : Vol. 02, Issue 02, May 2021

e-ISSN : 2745-9659

https://ijcis.net/index.php/ijcis/index

[14] Jannah, A. M., Muqorobin, M., \& Widiyanto, W. W. (2020). Analysis Of Kids Garden Dapodic Application System. International Journal of Computer and Information System (IJCIS), 1(3), 55-58.

[15] Efendi, T. F., \& Wihartati, A. P. (2021). Decision Support System for Share Investment Using The Capital Assetpricing Method (CAPM). International Journal of Computer and Information System (IJCIS), 2(1), 18-22. 